\title{
THE PRIVACY OF GOVERNMENT EMPLOYEES
}

\author{
Willitam A. Creech*
}

Notwithstanding the American public's long-standing interest in privacy, it is disturbingly common in our society for employers-both private and governmentalto make searching inquiries into the actions, habits, associations, and thoughts of their employees. Important technological and scientific advances have greatly facilitated the invasion of individual privacy, and, indeed, some of the "sciencefiction" envisionings of Aldous Huxley ${ }^{1}$ and George Orwell ${ }^{2}$ seem well on their way to realization in numerous sectors of American life. Almost all of the various privacy-invading techniques that are decried by journalists and other observers of American society ${ }^{3}$ have been used from time to time by employers in dealing with their employees. It is particularly shocking to discover that the record of federal, state, and local governments in dealing with their employees is hardly better in this regard than that of private industry.

Recent disclosures by congressional committees have focused attention on the federal government's lapses in its respect for the personal privacy of its employees. ${ }^{4}$ While the rights of only about two and 2 half million federal employees are directly involved, the long-term effect of eroding the bastions of individual privacy would transcend numerical limits, infuencing by example the practices of other public employers at the state and municipal levels and of private employers as well. ${ }^{5}$ On the other hand, the impact of the federal government's activities on our national ethos is such that efforts to reform its attitudes on employee privacy could have a carryover effect to other levels of government and into the private sector. The publicity given to privacy issues by congressional activities in the recent past has,

-A.B. I948, University of North Carolina; LL.B. 1958, Georgetown University. Member of the North Carolina bar. Formerly Chief Counsel and Staff Director, Subcommittee on Constitutional Rights of the Senate Committee on the Judiciary. Author, Psychological Testing and Constitutional Rights, 1966 Duks L.J. 332.

1 Aldous Huxiey, Brave New World (1931).

${ }^{2}$ Griswold v. Connecticut, 38 r U.S. 479 (1965).

${ }^{3}$ E.g., Vance Packard, The Naked Society (I964); Myron Brenton, The Privacy Invaders (I964).

-This article does not take up the privacy of the largest group of federal employees, namely, the members of the armed forces. See generally Sewell, The Serviceman's Right to Privacy, I6 VA. I. WEEKLY Dicta CoMp. 85 (1965); Murphy, The Soldier's Right to a Private Life, Military L. Rev., April 1964 , p. 97. However, this is an extremely interesting aspect of the privacy problem, because there are few other areas of American life, outside of prisons, where privacy is so ruthlessly stripped away. The assertion of some military men that privacy is sacrificed only to the extent required by the military mission should not, of course, be accepted too readily.

c "Attitudes and procedures affecting Federal employees have a way of pervading our whole society, governing the employer-employee relationship wherever it is found. This is especially true today when in the wake of expanding Federal activities private industries and firms hold contracts with the Federal Government which subject their employees to Federal personnel rules and to Federal industrial security regulations." Senator Sam J. Ervin, Jr., II2 CoNG. Rec. I5347 (daily ed. July I 8, I966). 
I think, already generated an increased public sensitivity to privacy invasions of all kinds.

Among the most active congressional committees in pursuing privacy questions is the Subcommittee on Constitutional Rights of the Senate Committee on the Judiciary, ${ }^{6}$ which is chaired by Senator Sam J. Ervin, Jr., of North Carolina. Also conspicuous in the fight for a resuscitation of privacy as a value in government and American life generally has been a special subcommittee of the House Government Operations Committee, ably led by Representative Cornelius E. Gallagher of New Jersey, ${ }^{7}$ and the Subcommittee on Administrative Practice and Procedure of the Senate Committee on the Judiciary, under the chairmanship of Senator Edward V. Long of Missouri. ${ }^{8}$ Each of these committees has from time to time focused particularly on the rights of Government employees, but the most substantial effort toward guaranteeing these rights is Senator Ervin's proposal in August rg66 of a bill designed to protect the rights of employees in the executive branch against privacy invasions and various types of coercion. ${ }^{\theta}$ The text of this proposed bill, which is co-sponsored by thirty-four senators in addition to Senator Ervin, is appended to this article, and its substance is commented on here and there throughout.

The current disclosures by congressional committees ${ }^{10}$ and in popular articles ${ }^{11}$ often tend to suggest that the problem of privacy invasion is an incurable one in a technological age and in an expanding economy where federal and state government bureaucracy every day increases the scope of its activities. The reported intrusions can be meaningfully analyzed for their philosophical, intellectual, sociological, legal, and political meanings. We can, however, also analyze them as practical problems in the control of bureaucracy-problems capable of solution by means of existing controls which can be exercised by Congress, the President, and the people. The purpose here is to point out some influences less frequently acknowledged as causing privacy invasions, to demonstrate the complexity of some of

\footnotetext{
- See, e.g., Staff of Subcomm. on Constitutional Rights, Senate Comm. on the Judiciary, 87th Cong., 2D Sess., Wiretapping and Eavesdropping Summary-Report of Hearings 1958-61 (Comm. Print 1962); Hearings on Testing Procedures and the Rights of Federal Employees Before the Subcommittee on Constitutional Rights of the Senate Committee on the Judiciary, 89th Cong., Ist Sess. (1965).

"E.g., Hearings on the Use of Polygraphs as "Lie Detectors" by the Federal Government Before a Subcommittee of the House Committee on Government Operations, 88th Cong., 2d Sess. (1964), 89th Cong., 1st Sess. (1965); Hearings on Invasion of Privacy Before a Stubcommittee of the House Committee on Government Operations, 89th Cong., Ist Sess. (1965).

${ }^{8}$ E.g., Hearings on Invasions of Privacy by Government Agencies Before the Subcommittee on Administrative Practice and Procedure of the Senate Committee on the Judiciary, 89th Cong., Ist Sess. (I965), 89th Cong., 2d Sess. (1966).

The bill was introduced twice in the Senate, the second time for the purpose of adding co-sponsors. S. 3703, 89th Cong., 2d Sess. (Aug. 9, I966); S. 3779, 89th Cong., 2d Sess. (Aug. 26, I966).

${ }_{10}$ See notes 6.8 supra.

${ }^{11}$ Sec, e.g., Lear, Whither Personal Privacy?, Saturday Review, July 23, 1966, p. 36; In Defense of Privacy, Time, July 15, 1966, p. 38; There's a Dossier on You, Washington Post (Outlook), May 29, 1966, p. E-I; A Government Watch on 200 Million Americans?, U.S. News \& World Report, May 16, 1966, p. 56; Esquire, May 1966 (containing a series of articles); Snooping Electronic Invasion of Privacy, Lifc, May 20, x966, p. 38 .
} 
the privacy problems that have arisen, and to note some of the existing resources in our political system which can be marshalled to protect our newly-defined right to privacy.

\section{Privacy Invasions}

\section{A. "Background Investigations" and Other Inquiries}

Common practice has long established the privilege of an employer-private or governmental-to inquire into certain areas of a person's personal and professional background when he applies for employment. The employer's interest in the applicant's past is presumptively legitimate, although the relevance of particular inquiries may occasionally be in doubt. ${ }^{12}$ Moreover, the job applicant in seeking a particular position can fairly be said to have consented to an investigation of his qualifications for that employment. This consent is freely enough given to authorize investigation of matters that are obviously relevant, but there is some doubt that implied consent supports a full "background investigation" involving contacts with persons other than previous employers and those expressly listed as references on an employment application. Obviously, implied consent ought not to be relied on where the applicant is ignorant of the type of investigation that will be conducted or if he is misled by the interviewer or the application form.

Unfortunately, improper invasions of employee privacy by federal agencies are not restricted to unwarranted prying into the personal life of prospective employees ${ }^{13}$ but include many kinds of surveillance and probing of employees' activities after they have been hired. ${ }^{14}$ The reliance on implied consent to justify encroachment on privacy in the hiring process does not automatically carry over to the employee who is already on the government's payroll. Few would argue that acceptance of a

\footnotetext{
${ }^{12}$ In Scott v. Macy, 349 F.2d I82 (D.C. Cir. I965), the plaintiff argued unsuccessfully that "homosexual conduct" was not a proper ground for rejection from certain areas of federal employment.

${ }^{13}$ Scott v. Macy, supra note 12, suggested for the first time that applicants for federal employment may be entitled to a degree of procedural due process where the grounds for rejection are such as to reflect on their moral character.

14 In the early years of the federal and state loyalty-security programs, these background investigations often invaded and questioned the individual's freedom to associate with whom he pleased, his right to speak, read, and write unpopular opinion, his right to travel where he pleased free of surveillance or restriction, and many others areas of his personal life. In some instances, investigators revealed conduct which in other times or other circumstances would merely have raised social eyebrows or marked the person as a nonconformist, but which under the standards of the security program made him a security risk. The revelations to his employer or his potential employer provided the basis for adverse personnel decisions which affected his livelihood and his reputation not only in government but in private industry as well. The issue was presented in Congress and the courts as a problem of providing due process for government employees, rather than one of invasion of privacy, yet the issue of privacy, while not expressed, was always implicit. See generally Razph S. Brown, Loyalty and SEcurty (1958); Association of the Bar of the City of New York, Report of the Special Committee on the Federal LoyaltySecurity Program (1956); John L. O'Brian, National Security and Individual Freedom (1956); Eleanor Bontecou, The Federal Loyalty-Security Program (1953); Alan Barth, The Loyalty of FREE MEN (I95I). See also text accompanying notes $54-60$ infra on the emergence of constitutional protection for government employees.
} 
salary is equivalent to a waiver of all one's rights as a citizen, and the right to resign is hardly a suitable foundation on which to predicate implied consent to whatever the government may exact in the way of piecemeal surrenders of privacy. Only where continued subjection to investigatory efforts is a known and unavoidable condition of employment-as in positions closely affecting national security-does the consent rationale have any merit, and even here it must be relied upon with caution. In situations where implied consent does not operate, submission to an invasion of privacy has often been made voluntary, but even here employees have often felt varying degrees of coercion to allow their privacy to be usurped. ${ }^{15}$ The ease with which administrators can thus encroach upon the privacy of their subordinates makes vigilance especially desirable.

The routine background investigation and other investigatory undertakings are, of course, widely accepted as essential to sound administration, ${ }^{16}$ and it is impossible to expect the government to dispense with them. However, it is essential to ponder such questions as whether the need for a full-scale investigation is rationally determined in accordance with established criteria, whether prospective employees are alerted to the scope of the investigation they are letting themselves in for, whether inquiries are limited to relevant matters, and whether, because of questioning techniques, they become the means of spreading unsupported rumor. We will have occasion to note below how the Department of Defense, in the well-known Skallerup Memorandum, has attempted to curb investigators in their pursuit of facts not bearing directly on the issue of national security. ${ }^{17}$ It is unfortunate, however, that security checks and other investigations of present and prospective employees are not often expressly characterized as involving privacy problems. Until investigations are firmly linked to the overriding issue of the employee's right to personal privacy, abuses will be difficult to detect and correct.

\section{B. Surveillance and Eavesdropping}

Perhaps the leading type of privacy invasion by private industry is the widespread use of covert surveillance and eavesdropping techniques. ${ }^{18}$ These techniques include

\footnotetext{
${ }^{16}$ See notes $45-46$ infra and accompanying text.

${ }^{10}$ Abuses are the fault not solely of the Executive Branch but also of Congress. Presidential authority has occasionally been employed to promote privacy invasions. Perhaps the most celebrated instance of this, in the interest of national security and law enforcement, is a 1940 directive of President Roosevelt authorizing the Attorney General to intercept telephone communications in national security and kidnaping cases. In the intervening years, the FBI has continued to rely on this letter as a wholesale grant of authority to wiretap in such cases. See Hearings on Wiretapping and Eavesdropping Before the Subcommittee on Constitutional Rights of the Senate Committee on the 7udiciary, 87th Cong., xst Sess. 353 (I96I) (testimony of Assistant Attorney General Miller). A brief history of administrative advocacy of wiretapping for security reasons is contained in Hearings Before Subcommittee No. I of the Scnate Committee on the Judiciary, 77th Cong., Ist Sess. passim (194I). See generally Westin, The WireTapping Problem: An Analysis and a Legislative Proposal, 52 ColuM. L. Rev. I67, I86-87 (1952).

${ }_{17}$ See notes 66-68 infra and accompanying text.

${ }^{18}$ See, e.g., Meany, Labor's Efforts to Sectire Privacy, I6 VA. L. Weekly Dicta Comp. ri6 (1965).
} 
closed-circuit television, one-way mirrors, hidden microphones, tapped telephones, and so forth. The purpose may be to detect pilferage or to check up on employee diligence or morale or on the quality of service being rendered to the public. Similar motivations may also prompt public employers to adopt such expedients. For example, at the federal government level, the Post Office Department has publicly admitted that on occasion it clandestinely spies upon its employees while they are working on the job. Last year Chief Postal Inspector H. B. Montague testified:

The need for surveillance of postal activities in order to keep depredations on the mail at a minimum has been proven over the long history of the Post Office Department. The lookout or observation galleries now in use for that purpose have been time tested. . . Employees do not, of course, generally know when the galleries are being used by inspectors for observation purposes. ${ }^{10}$

There was, however, an encouraging word concerning an even more egregious privacy invasion:

The lookouts in the men's rooms were discontinued on December ro, rg64, on instructions of Postmaster General Gronouski. That action was taken after he had discussed the matter with numerous individual employees throughout the country, with employee organizations, with various Congressmen and Senators, and with us. $\mathrm{He}$ issued those instructions so that the lookouts have been taken out of men's rooms. ${ }^{20}$

While no one would doubt the importance of preserving the security of the mails, most would agree that there must be a limit to the lengths to which that mission is carried. The conflict between end and means is here extraordinarily clear, but if one were searching for the extreme case to illustrate the tension between the prevention of theft and the preservation of employee privacy (as well as the role of economic coercion in inducing "consent"), he could not do better than to recall the indignities to which African diamond miners are said to have been historically subjected. Clearly we are dealing with hard issues, where the merits of either side of the argument are substantial.

For another illustration of surveillance, we turn to the state government level, where monitoring of classroom activities and conversations without the consent or knowledge of teachers, parents, or students has become a common problem. The practice is justified as a means of evaluating teachers' performance by direct observation. However, it is objected that surveillance inhibits the dialogue, open expression, and personal rapport necessary in an effective educational system and that the system is subject to serious abuses. Some educational and professional groups have decried this practice, which recently was graphically described in these words:

[S] ome "professional" educators have for years used electronic devices to tell them what is going on in classrooms. ... Anyone who has frequent contact with

\footnotetext{
${ }^{10}$ Hearings on Invasions of Privacy by Government Agencies, supra note 8, at 69-70.

${ }^{20} \mathrm{Id}$. at 73 .
} 
teachers can collect testimonials concerning the use of these intercom systems to "observe" teachers in action.

... Obviously, it helps in making general announcements to the entire school, but it also can be used to listen when classes are in session, when teachers gather after school, or when parents come to talk with teachers.

There is ample evidence that some principals use it for such purposes without the knowledge or consent of teachers. Most school intercom systems can be activated from the office without alerting classroom teachers to the fact that someone is listening. There are no lights or warning buzzers to indicate when the device is on. ${ }^{21}$

Again the issue is difficult.

\section{Lie Detectors}

One report has it that the nonsecret federal agencies possess over 500 polygraph machines and that in one recent year over 20,000 lie detector tests were administered to Government employees and job applicants. ${ }^{22}$ Criticism of the machine is widespread, based on its dubious accuracy, the lack of qualifications of many operators, and the general belief that it is an unwarranted invasion of the private personality. ${ }^{23}$ Because it proceeds on the basis that the individual is somehow obligated to prove his innocence, the lie detector is as objectionable in our society as any device yet developed.

Senator Ervin has summed up the case against the lie detector by asserting that "polygraph tests operate on the basis of emotional responses which a brazen liar might successfully dissemble while a timid man would fail."24 The Senator's pending bill would outlaw polygraph testing of any Government employee where it is "designed to elicit from him information concerning his personal relationship with any person connected with him by blood or marriage, or concerning his religious beliefs or practices, or concerning his attitude or conduct with respect to sexual matters."25

It was a hopeful development when the President established in December 1965 an interagency committee under the leadership of Chairman Macy of the Civil Service Commission to study the uses of lie detectors in the Government. ${ }^{2 B}$ This

\footnotetext{
${ }^{21}$ Carbone, Big Brother is in the Office: Invasion of Privacy in the Schools, Phi Delta Kappan, Sept. 1965, p. 34 .

'2 Gallagher, Bases for Congressional Investigation of Privacy Violations, 16 VA. L. WeEkLY Dicta CoMr. 42, 47 (1965).

${ }^{28}$ See generally Hearings on the Use of Polygraphs as "Lie Detectors" by the Federal Government, supra note 7; Burkey, The Case Against the Polygraph, 51 A.B.A.J. 855 (1965); The Truth About "Lie" Detectors, The American Federationist, Nov. 1964, p. 13; Levin, Lie Detectors Can Lie, 15 LAs. L.J. 708 (1964); Pfaff, The Polygraph: An Invaluable Judicial Aid, 50 A.B.A.J. 1130 (1964) (use should be limited to good equipment and competent operators); Comment, The Polygraph in Private Industry: Regulation or Elimination?, I5 Buffalo L. Rev. 655 (1966); Note, Lie Detectors in Private Employment: A Proposal for Balancing Interests, 33 Geo. Wash. L. Rev. 932 (1965).

24 Letter from Senator Sam J. Ervin, Jr., to the Editors, American Bar Association Journal, May 26, 1964 , reprinted in 50 A.B.A.J. 602 (1964).

${ }^{25}$ S. 3779 , 89th Cong., 2d Sess. $5 \mathrm{I}(\mathrm{g})$ ( 1966$)$. (See Appendix.)

${ }^{26}$ See House Foreign Operations and Government Information Subcommittee Press Releasc, Dec. I3, 1965.
} 
action implemented a recommendation by a congressional committee following earlier criticism on the validity of polygraph tests. ${ }^{27}$ Several states have laws prohibiting public (as well as private) employers from using lie detectors on employees or job applicants. ${ }^{28}$ Such legislation reflects a legislative judgment that should recommend itself to Congress. We are now awaiting the report of the interagency committee charged with reviewing the problem.

\section{Psychological Testing}

The use of tests designed to reveal psychological instability has been widely condemned on the ground of their alleged invalidity as well as because of the necessary penetration into intensely personal and private matters. I have recently had occasion to deal with this subject at length, in another journal, ${ }^{29}$ and will not repeat that discussion here other than to observe that the purposes sought to be achieved through psychological testing are various and that available safeguards have not been fully implemented. The chief such needed safeguards include assurance that tests will receive qualified evaluation and that results will be kept confidential as well as the extension to persons adversely affected of the right to challenge the findings. In addition, a strict limitation on the type of employment warranting use of privacyinvading personality tests was suggested. Senator Ervin's proposed bill goes farther in prohibiting all tests that make inquiries concerning the individual's family relations, religion, or sexual practices or attitudes. Such a prohibition would effectively rule out psychological tests of the most common varieties.

\section{E. Other Privacy Questions: Dossiers and Questionnaires}

The collection of information concerning government employees goes on and on. Automated data retrieval makes information accessible through multiple cross references and thus increases the likelihood of its use. According to one source,

The U.S. Civil Service Commission, which maintains a dossier on nearly everyone who has applied for federal employment since 1939 , reportedly has nearly 250,000 dossiers that contain adverse information.

\footnotetext{
${ }^{27}$ See ibid.; Dawson, Use of Polygraphs as "Lie Detectors" by the Federal Government (Tenth Report by the Committee on Government Operations), H.R. ReP. No. 198, 89th Cong., Ist Sss. 2 (I965).

s8 Alaska Stat. $\$ 23.10 .037$ (1965); Mass. Laws ANN. ch. I49, $\S 19 B$ (1965); N.J. Sess. Laws I966, ch. II4 (effective June 17, 1966); ORE. Rev. StAT. $\$ \$ 659.225,659.990$ (1965); R.I. Gen. LAws $\$ \$ 28-6.1-1$ to -2 (1965); Wash. Rev. CODE $\$ \$ 49.44 .120,49.44 .130$ (1965). See also Cal. LabOR CODE $\$ 432.2$ ( 1965 ) (does not include the state among those employers prohibited from using lie detectors).

${ }^{20}$ Creech, Psychological Testing and Constitutional Rights, r966 DuxE L.J. 332. See also Mirel, The Limits of Governmental Inquiry into the Private Lives of Government Employees, 46 B.U.L. REv. I (1966), in which the author argues strenuously for properly administered psychological tests for Peace Corps members under conditions insuring confidentiality. General references include Hearings on Psychological Testing Procedures and the Rights of Federal Employees, supra note 6; PHILIP E. VERNON, Personazity Assessment: A Crimcal Survey (1964); Frank Samuel Freeman, Theory and Practice of Psycholocical Testing (3d ed. 1962); Martin L. Gross, The Brain Watchers (ig62) (a popular study); Sadoff, Psychiatric Involvement in the Search for Truth, 52 A.B.A.J. 25 I (I966).
} 
Its central index of approximately $7,500,000$ dossiers is just one of the many central files on individuals that has grown to enormous proportions in recent years. The Defense Department maintains a central index of members of the armed forces, civilian employees, and a great many other people, including scientists working for defense contractors. ${ }^{30}$

These figures give an impression of the sheer volume of the information collected and suggest that its reliability is not beyond doubt. The employee or other citizen has no right of access to his own file, however, ${ }^{31}$ and errors may therefore go undetected and uncorrected. The long and only partially successful battle waged by individuals discharged from government service on the basis of secret information ${ }^{32}$ is only one facet of a larger privacy problem, namely, the Government's assumption of the responsibility of collecting sensitive personal information without adequate safeguards over its accuracy and accessibility and over the uses to which it is put. Recent proposals for a Federal Data Center have added to the interest in the problem as well as to its potential magnitude. ${ }^{33}$

The inquiry itself may raise serious privacy issues if the matter sought to be learned is of an especially personal variety and not within the employer's normal prerogative. The issue is particularly acute where the governmental employer intrudes in some manner on activities protected by the first amendment. Such a case was Shelton v. Tucker, ${ }^{34}$ in which Arkansas school teachers refused to file required affidavits listing all of their organizational affiliations, including those of a political and religious nature. The Supreme Court, in a five-to-four decision, invalidated the statutory requirement on first amendment principles, which, it was held, prohibit undue inhibition of the freedom of association, and noted that all of the employer's legitimate purposes could have been achieved by less intrusive means. ${ }^{35}$

Other privacy invasions may lack first amendment overtones but be similarly

${ }^{30}$ VANCE PACkard, The NAKed Societr 8 ( 1964$)$.

${ }^{91}$ Recent legislation amending $\$ 3$ of the Administrative Procedure Act, 80 Stat. 250 (1966), amending 60 Stat. 238 ( 1946$), 5$ U.S.C. 1002 ( 1964$)$, to become effective on July 4,1967 , is designed to make information in Government files more generally available to the public. However, it includes an exemption from the disclosure requirements for "personnel and medical files and similar files the disclosure of which would constitute a clearly unwarranted invasion of personal privacy." This recognition of the right of privacy is gratifying, though, of course, it forfends only invasions by third parties, not by the Government itself. Construed in the light of its evident purpose [see H. REP. No. 1497, 89th Cong, 2d Sess. II (1966)], the quoted exemption should not prevent a Government employee from obtaining access to his own personnel file.

${ }^{32}$ See generally KeNNETH Culp Davis, Administrative Law 5 7.13 (1958, Supp. 1965); Note, Dismissal of Federal Employees-The Emerging Judicial Role, 66 CoxuM. L. Rev. 7I9 (1966). Sce also notes $54-60$ infra and accompanying text.

${ }^{33}$ See notes $79-82$ infra and accompanying text.

84 ${ }_{3} 64$ U.S. 479 ( 1960 ).

as The Court gave weight to the lack of confidentiality of the information supplied (id. at $486-87$ ) and stated the balancing-of-interests principle as follows: "In a series of decisions this Court has held that, even though the governmental purpose be legitimate and substantial, that purpose cannot be pursued by means that broadly stifle fundamental personal liberties when the end can be more narrowly achieved. The breadth of legislative abridgment must be viewed in the light of less drastic means for achieving the same basic purpose." Id. at 488 . (Footnotes omitted.) 
deserving of attention. Recently, Senator Ervin has uncovered two significant privacy invasions of such a variety indulged in by the federal government against its employees. The first is the conflict-of-interest questionnaire which a large number of federal employees are required to fill out periodically. ${ }^{36}$ The employee must detail all of his financial affairs and those of members of his household in order to demonstrate that he is subject to no conflicts of interest in carrying out his day-to-day administrative functions. The purpose, the prevention of conflicts of interest, is indeed commendable, but it appears from Senator Ervin's inquiries that the form has been required of thousands of persons whose positions raise no substantial possibility of such conflicts. ${ }^{37}$ Because the inquiry is extraordinarily broad and covers matters that most persons consider private, ${ }^{38}$ the practice should be strictly limited to persons in positions of particular importance, such as those persons empowered to award contracts or compromise claims. Surely the form is a questionable device at best, since it requires persons to demonstrate periodically their innocence of violations of the numerous federal laws governing conflicts of interest. ${ }^{39}$

Another privacy question recently brought to light by Senator Ervin and his Constitutional Rights Subcommittee is the use by the Civil Service Commission of so-called minority status questionnaires. ${ }^{40}$ These questionnaires, which ask employees to record their ethnic background, raise delicate questions of policy and propriety, and they are discussed at some length below as a means of demonstrating the complexity to which some privacy questions can give rise.

\footnotetext{
${ }^{\text {"Fo }}$ For a full discussion of the questionnaire, its scope, and its use, and relevant source materials, see Senator Ervin's remarks in 112 CoNG. REc. $15356-62$ (daily ed. July 18,1966 ) and id. at 17814,17816 (daily ed. Aug. 9, I966). The basic regulations promulgated by the Civil Service Commission appear in 5 C.F.R. $\$ 735.101-.412$ (Supp. rg66).

s7 The Civil Service Commission regulations authorize requiring statements from "employees in positions specifically identified in the agency regulations as positions determined by the agency head as requiring the incumbent thereof to report employment and financial interests in order to carry out the purpose of law, the Executive Order, this part, and the agency regulations." 5 C.F.R. $\$ 735.403$ (Supp. 1966). Examples of the unwarranted extension of the reporting requirement include questionnaires sent to newsmen who had been selected by the U.S. Information Agency to serve the Government during times of emergency but whose position carries no salary and involves no present duties. II2 Cong. Rec. 15356-57 (daily ed. July 8, r966). In addition, Senator Ervin also reported:

"As examples, however, we noted that the Post Office Department requires over 10,000 regular cmployees to disclose their personal finances and has appointed 513 deputy ethical conduct counselors, while the GS-3 employees in the Smithsonian Institution must disclose. Other agency replies show that $\mathrm{r}, 500$ State Department employees, including interior decorators, 9,420 regular and special employees in the Department of Health, Education, and Welfare, 3,500 in the Commerce Department, and 8,303 in the Treasury Department must report."

Id. at $\times 7816$ (daily ed. Aug. 9 , I966).

38 "Americans are loath to reveal their personal assets and income, for many reasons, and many will resist bitterly any efforts to make them do so." Special Coms. on the Federal. Conflict of INTEREST LAfs, Ass'N of the Bar of the City of New York, Conflict of INTerest and Federal Service 255 $(x g 60)$. This study of the question argued strongly against the imposition of disclosure requirements, partly because of the probable adverse effects on recruitment.

${ }^{30}$ See generally Bayless Manning, Federal Conflict of Interest Law (1964).

${ }^{10}$ For a full discussion of these questionnaires, reactions to their use, and source materials, see 112 CoNg. Rec. $15348-55$ (daily ed. July 18,1966 ) and $i d$. at $1781_{4-15}$ (daily ed. August 9, 1966).
} 
II

\section{Analyzing Privacy Problems}

Many laudable and weighty reasons are advanced by zealous and well-meaning men as justifications for invading the privacy of government employees. National security, law enforcement, prevention of thefts of government or citizens' property, economy and efficiency in government, foreign relations considerations, ${ }^{41}$ prevention of conflicts of interest, and protection of minority rights are among the high purposes most often cited by officials at all levels of government. No reasonable man can quarrel with such purposes, but it is not difficult to quarrel with those who show no discrimination in selecting means to achieve these ends. ${ }^{42}$

Congressional investigations indicate that administrators who utilize questionable devices for surveillance and information-gathering fall roughly into two general categories. The first group gives careful consideration to the substantive goal they are seeking to achieve in their programs and weighs the public interest in that goal against the individual employee's interest in maintaining his privacy against the particular encroachment. Using this balancing technique, they may on occasion make a calculated decision to obtain information through particular privacy-invading methods, but they will continue to recognize the legitimacy of privacy claims, providing where possible for obtaining voluntary employee consent to the invasion and rigidly maintaining the confidentiality of the information elicited. On the other hand, there is the second group, which treats efficient achievement of narrowly conceived substantive goals, important or unimportant, as the sole object of administration. Members of this group are apt to be narrowly based specialists or timid administrators who are willing to turn matters over to the specialists-the personnel experts, the psychologists, the trained investigators, or the lie detector operatorsthereby waiving responsibility rather than assuming it.

Administrators of the first variety have grasped the essential significance of privacy as a value. They realize that it is far from being an absolute, that it must yield to governmental interests in a wide variety of cases where the two come into conflict; but they are also sensitive that privacy may decisively affect the choice of means and that it is always relevant whether another method of achieving the same goal, or of approximating it, might involve a lesser intrusion on personal privacy.

An example of the extreme complexity of privacy problems viewed in this light is the issue raised in recent months by Senator Ervin with the Civil Service Com-

\footnotetext{
12 Mirel, supra note 29, emphasizes economy as well as foreign relations considerations in discussing psychological testing of Peace Corps volunteers.

42 "Experience should teach us to be most on our guard to protect liberty when the Government's purposes are beneficent. Men born to freedom are naturally alert to repel invasion of their liberty by evil-minded rulers. The greatest dangers to liberty lurk in insidious encroachment by men of zeal, wellmeaning but without understanding." Olmstead v. United States, 277 U.S. 438, 471 (r928) (dissenting opinion of Brandeis, J.). The case involved wiretapping, making Justice Brandeis's remarks dircetly relevant to this discussion of privacy problems.
} 
mission over the so-called minority status questionnaire, which was adopted by the Commission in the interest of assuring equal employment opportunities and fair treatment for members of minority groups. ${ }^{43}$ The questionnaire is authorized for all federal employees and involves giving name and social security number and indicating by a checkmark whether the employee is "American Indian," "Negro," "Oriental," "Spanish-American," or "None of these."44 Although the directions to supervisors state that "no employee is required to complete the questionnaire against his wishes and no disciplinary action will be threatened or taken for his failure to do so," there are also recommended procedures for obtaining compliance with the survey. A review of agencies' practices in obtaining completed questionnaires caused Senator Ervin to be concerned about a lack of the voluntariness which the Commission claimed for the survey. Many instances of subtle coercion were reported, ${ }^{45}$ and the evidence suggests that the alleged voluntariness did not cure the privacy-invading tendency of the questionnaire. An important lesson can be learned from this experience with "voluntariness."46

Apart from the question of coercion, a privacy problem is presented by the questionnaire itself. The sensitivity of the subject of race in our society need hardly be dwelt upon, and many may be offended by this governmental interest in their ethnic background. The privacy problem is particularly acute in the case of those whose racial characteristics are not apparent to the eye or ear. Persons of mixed blood may be unable to answer the questionnaire accurately, and many of these persons would prefer not to make their heredity a matter of public record. As it has turned out, members of Spanish-speaking groups and others have objected to ethnic identification for work purposes, and many employees, both white and nonwhite, have deliberately

\footnotetext{
¿see note 40 supra. .

th On the reverse side, employees and applicants are told:

"The federal government and your employer want to be sure that every individual whatever his race or national origin gets fair and equal treatment. To do this, we need to know how many minority group employees there are, what kinds of jobs they hold, what grade level their jobs are, and other things that will show whether or not there is discrimination. Minority group records are being set up for this purpose.

"You are asked to help by checking the block on the other side of this card which describes your race or national origin. Your answer will be kept confidential and will not be used against you in any way." II2 CONG. REc. I5352 (daily ed. July 18, 1966).

"In one agency, a list of those employees who refused to fill out the questionnaire was sent to the regional headquarters of the agency. II2 CoNG. Rec. 15348 (daily ed. July 18, 1966). Also, where refusals were listed, follow-up questionnaires were distributed stressing the need for the "voluntary" forms. Id. at 15349. Admonishments are given by superiors urging roo\% participation. Ibid.

"Senator Ervin expressed the lesson as follows:

"It appears to me that the 'voluntary' nature of this questionnaire raises issues similar to the use of polygraphs and psychological tests by Government. When a man wants a job, when he knows that his cooperation or lack of it in such data collecting may mark him in personnel files as well as in his supervisor's eyes, and when a supervisor knows that his own performance in obtaining compliance is being watched, there is implicit in such procedures economic coercion to an employee's consent to this invasion of his privacy."

II2 Cong. REc. I5349 (daily ed. July 18, I966).
} 
filled out the form incorrectly as a protest against the inquiry. Government employee organizations have also expressed themselves against the questionnaire.

The issues raised by the minority status questionnaire prove to be exceedingly complex when they are subjected to analysis. Objections to it are grounded on not only the privacy invasion but also on the implication that the time-honored merit system of the Civil Service may be set aside to allow preferences for minority groups, the possibility of misuse of data for discriminatory purposes, and the availability of other, less intrusive, means of accomplishing the Civil Service Commission's laudable objective of insuring against discrimination in employment. On the other hand, Chairman Macy and the Civil Service Commission have concluded that the privacy invasion or other offensiveness of the questionnaire is warranted by the object in view; the ability to use the punch cards for statistical analysis of the situation in particular agencies, he believes, will greatly advance the campaign against discrimination in employment. ${ }^{47}$ The complexity of the issue is illustrated by the presence of civil rights and civil liberties groups among the supporters of both positions.

The dispute over the minority status questionnaire illustrates how a privacy issue can be beclouded by issues of other kinds-such as the appropriateness of a particular method of achieving civil rights objectives-and how privacy is simply one of many values that enter into the decision-making process. Senator Ervin's efforts ought properly to be viewed as a commendable effort to upgrade privacy as a value in the Government's dealings with its employees.

\section{III}

\section{Upgrading Privacy in Government Employment}

\section{A. Legal Controls: The Constitutional Issues Briefly Stated}

\section{The Constitutional Status of Privacy}

In Griswold v. Connecticut, ${ }^{48}$ the Supreme Court, in striking down the Connecticut birth control law in its application to married couples, defined a right to privacy for the first time as an independent constitutional doctrine. The Court found that, although it was not specifically guaranteed as a constitutional right, privacy's various components could be found in the "penumbras" of the first, third, fourth, fifth, and ninth amendments. Mr. Justice Douglas, in the majority opinion, looked at these guarantees and noted: "[S]pecific guarantees in the Bill of Rights have penumbras, formed by emanations from those guarantees that help give them life

\footnotetext{
${ }^{47}$ Replying to the Subcommittee's letter, the Civil Scrvice Commission reported that it had "reexamined the minority statistics procedures in light of ... [Senator Ervin's] comments and ... [found] them both essential and proper to our carrying out our responsibilities under the Equal Employment Opportunity Program." Letter from Chairman John W. Macy, Jr., U.S. Civil Service Commission, to Senator Sam J. Ervin, Jr., reprinted in II2 CoNc. Rec. 15354 (daily ed. July 18, 1966).

${ }^{ \pm 8}{ }_{381}$ U.S. 479 (1965); see Symposium on the Gristuold Case and the Right of Privacy, 64 Mictr. L. REv. 197 (1965).
} 
and substance." ${ }^{\text {"49 }}$ Under this approach, he said, "the right of privacy which presses for recognition here is a legitimate one." ${ }^{\prime 50}$ Mr. Justice Harlan, concurring in the judgment, found the right of privacy a fundamental right "implicit in the concept of ordered liberty" ${ }^{15}$ and, therefore, protected by the due process clause of the Constitution.

In still another opinion, Mr. Justice Goldberg, joined by the Chief Justice and Mr. Justice Brennan, stated that the "concept of liberty protects those personal rights that are fundamental, and is not confined to the specific terms of the Bill of Rights."52 In a statement which could have broad implications for government management techniques and devices used to intrude on employee privacy, Justice Goldberg continued:

In a long series of cases this Court has held that where fundamental personal liberties are involved, they may not be abridged by the States simply on a showing that a regulatory statute has some rational relationship to the effectuation of a proper state purpose. "Where there is a significant encroachment upon personal liberty, the State may prevail only upon showing a subordinating interest which is compelling." Bates v. Little Rock, 36r U.S. 516, 524. The law must be shown "necessary and not merely rationally related, to the accomplishment of a permissible state policy." McLaughlin v. Florida, 379 U.S. I84, $x 96.53$

This is a clear spelling out, in a constitutional law context, of the "rule of reason" that we have already noted must be applied in evaluating a situation in which privacy interests have been sacrificed.

\section{The Constitutional Status of Government Employees}

The impact of the Griswold decision, it is submitted, will be felt in Congress as well as at administrative levels in the executive branch. Although the scope of the Court's mandate is not clearly defined and the criteria for its application are as yet undrawn, it is possible that the area of employee privacy will be one of the fields of application. Already the Supreme Court has begun to remove the chief obstacle that for a time appeared to insulate Government employees from constitutional protection in their dealings with the Government in its capacity as an employer, namely, the baneful distinction between "right" and "privilege." While at one time it was held that the absence of a constitutional "right" to federal employment permitted the Government to dismiss its employees arbitrarily, the Court has more

\footnotetext{
48 U.S. at 484 .

${ }^{80} 7 d$. at 485 .

${ }^{81}$ Id. at 500 [quoting Palko v. Connecticut, 302 U.S. 3I9, 325 (1937)].

"Id. at 486 .

${ }^{\mathrm{cs}} \mathrm{Id}$. at $49 \%$.

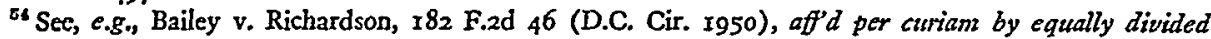
court, 34I U.S. 928 (195X). The history of this distinction and its gradual demise as a means of denying relief to public employees is recounted at greater length in Creech, supra note 29 at $358-61$. See also references in notes $\mathrm{I}_{4}$ and 32 supra.
} 
recently modified its position. In Wieman $v$. Updegraff, for example, the Court stated as follows:

We need not pause to consider whether an abstract right to public employment exists. It is sufficient to say that constitutional protection does extend to the public servant whose exclusion pursuant to a statute is patently arbitrary or discriminatory. ${ }^{55}$

While the Wieman case involved a state employee, the principle is equally applicable to federal employment. ${ }^{58}$ Also, protection against arbitrary dismissal seems easily extended to protect employees who are subjected to unreasonable infringements on their personal liberties.

The combination of the Griswold case's recognition of privacy as a constitutionally protected interest with the Supreme Court's new willingness to accord constitutional protections to public employees suggests a possible judicial role in protecting employee privacy. It is too early to tell what may develop, but a few random possibilities may be listed: (r) certain kinds of private employee conduct may prove to be beyond the range of legitimate government inquiry and may therefore be unacceptable as grounds for dismissal or other adverse treatment; ${ }^{67}$ (2) psychological testing may be subjected to judicial scrutiny concerning its validity and the relevance of the results in screening for particular jobs; ${ }^{58}$ (3) lie detectors may be held to infringe personal liberties if the results are made the basis for adverse personnel action; (4) refusals to submit to particular inquiries may be held an inadequate basis for dismissal or refusing employment; ${ }^{50}$ and (5) concern with privacy values may prompt imposition of strict procedural standards and influence construction of relevant legislation and administrative directives. ${ }^{80}$

\section{B. Legal Controls: Legislative Action}

Legislation to curtail the most objectionable practices of government in dealing with its employees is a possible means of achieving protection for privacy values. Senator Ervin's proposal of legislation establishing a sort of "bill of rights" for federal employees is an example of the kind of thing that might be done, as is a

\footnotetext{
${ }^{85} 344$ U.S. 183, 192 (1952).

vo See also Slochower v. Board of Higher Educ., 350 U.S. 55 (1956).

${ }^{57}$ In United Pub. Workers v. Mitchell, 330 U.S. 75 (1947), the Court appraised the Hatch Act's restrictions on personal freedoms of federal employees in the light of reasonableness of their relation to "efficiency" and other legitimate legislative objectives. Tests of reasonableness or relevancy might be similarly employed in applying a sort of substantive due process standard to privacy-invading measures employed by the Government qua employer. See Note, Dismissal of Federal Employees-The Emerging Judicial Role, 66 Cotum. L. Rev. 719, 733-41 (1966). But see Dew v. Halaby, 317 F.2d 582 (D.C. Cir. 1963$)$, cert. dismissed, 379 U.S. $904(\times 964)$.

${ }^{68}$ See Creech, supra note 29, at 358-72.

${ }^{50} \mathrm{Cf}$. Shelton v. Tucker, 364 U.S. 479 (1960), discussed in text accompanying notes $34-35$ stipra.

${ }^{\circ 0} \mathrm{Cf}$. Greene v. McElroy, 360 U.S. 474 (1959); Vitarelli v. Seaton, 359 U.S. 535 (1959); Colc v. Young, 35 I U.S. 536 (1956); Peters v. Hobby, 349 U.S. 33I (1955); Scott v. Macy, 349 F.2d 182 (D.C. Cir. 1965$)$.
} 
bill pending in the House of Representatives to prohibit, except in national security cases, the expenditure of any funds by any executive department or agency for the acquisition or use of a lie detector. ${ }^{61}$ Legislation restricting the use of lie detectors against public employees is already a notable accomplishment in several states. ${ }^{62}$

While legislation could do much to enforce recognition of privacy, greater overall benefits might be anticipated from the vigilant performance by congressional committees of their supervisory functions. Federal agencies are responsive to legislative criticism and influence, ${ }^{63}$ and, while some may object to some of the uses to which congressional influence is put, congressional pressure to vindicate the rights of Government employees is wholly proper. We have already noted the activities of several legislative committees, ${ }^{64}$ and each of these committees can point to significant reforms that they have induced through hearings and by investigation of complaints received from Government employees.

Another means by which congressional oversight is made meaningful is through the monitoring power of the General Accounting Office. As an arm of Congress, the GAO has the power to disallow any expenditures for unlawful purposes and to make a report on violations to interested congressional committees. ${ }^{65}$ This mechanism has proved valuable in controlling improper withholding of information by executive agencies and, given the appropriate guidelines, could check peepholing, eavesdropping, improper testing, and other privacy invasions.

\section{Administrative Action}

Specific action by Congress may have a considerable effect, but the Executive Branch has the final responsibility for personnel actions of all kinds. For this reason, change could be most easily generated within the Executive Branch itself, since privacy protection may require some sacrifice of substantive goals and administrators may feel more secure if their superiors have authorized according privacy priority over other objects. If privacy is to be given greater status, the leadership of the Executive Branch must assume the major burden. Likewise, the major blame for neglect of privacy values can be assigned to those who have failed to stress them in administration.

Perhaps the most notable example of administrative concern with ethical aspects of privacy-invading inquiries is the so-called "Skallerup Memorandum" of November $1962,{ }^{66}$ in which investigators and members of Defense Department Security Review Boards were admonished to take care

\footnotetext{
${ }^{61}$ H.R. 9878 , 89th Cong., Ist Sess. (1965).

as See note 28 supra.

${ }^{\text {os }}$ See generally Joseph P. Harris, Congressional Control of Aoministration (1964).

ot See rotes 6.8 supra.

65 Legislative Reorganization Act of $1946, \S \S 205,206,60$ Stat. 837,31 U.S.C. $\$ \S 59,60$ (1964).

${ }^{\circ 0}$ See Hearings on Psychological Testing Procedures and the Rights of Federal Employees, supra note 6 , at 199.
} 
not to inject improper matters into security inquiries whether in the course of security investigations or other phases of security proceedings. Religious beliefs and affiliations or beliefs and opinions regarding racial matters, political beliefs and affiliations of a nonsubversive nature, opinions regarding the constitutionality of legislative policies, and affiliation with labor unions are not proper subjects for such inquiries.

Inquiries which have no relevance to a security determination should not be made. Questions regarding personal and domestic affairs, financial matters, and the status of physical health, fall in this category unless evidence clearly indicates a reasonable basis for believing there may be illegal or subversive activities, personal or moral irresponsibility, or mental or emotional instability involved. The probing of a person's thoughts or beliefs and questions about his conduct which have no security implications, are unwarranted. ${ }^{67}$

The concern evinced by the Skallerup Memorandum was widely acclaimed by those who hoped for wider acceptance and implementation of the philosophy it expressed.8

An essential but often overlooked factor in regulating administrative practices affecting privacy interests is the organization of the department, agency, or unit. It is axiomatic that even the best intentions of Congress, the President, department head, or agency supervisor will be thwarted if the lines of authority are so dispersed that policy decisions are not implemented and effectively enforced all down the line, Lack of uniformity and centralization has been one of the chief complaints of congressional committees attempting to clarify the rights of employees where due process and civil liberties were at stake. The investigative service of the Defense Department, for example, with responsibility for in-house investigations of civilians, military employees, and defense industry, was composed of an interagency committee of seven parts, each operating alone but subject to some policy control. A year and a half ago, it was centralized under a single commander, making the whole investigative process subject to close management supervision and more receptive to policy pronouncements. Effective policy influence can now be exerted to procure compliance with the Skallerup Memorandum.

Several influences are working to check increasing government reliance on devices and instruments to investigate and monitor the activities and thoughts of employees. One is the demonstrated intellectual and political awareness by some administrators of the privacy issue and their willingness, given some appropriate support, to acknowledge publicly that privacy considerations constitute a component of their policy decisions. For example, the Federal Aviation Agency, in April 1965, issued an order outlining its policy for safeguarding individual rights of privacy in the conduct of agency investigations. ${ }^{69}$ The FAA said that the order was promulgated

${ }^{87}$ Quoted ibid.

${ }^{68}$ E.g., Letter from Senator Sam J. Ervin, Jr., to Secretary of State Dean Rusk, June 28, 1965, emphasizing the importance of the Skallerup Memorandum and suggesting that the State Department adopt a similar policy. III CoNc. REc. 25083 (daily ed. Oct. 5, I965) (introduced by Senator Ervin).

${ }^{\circ 0}$ Policy for Safeguarding Individual Rights of Privacy in the Conduct of Agency Investigations, FAA Order No. 1400.3, April 24, 1965. 
to assure the integrity of agency operations, safeguard the rights of employees and the public, and to inspire confidence in the agency's actions.

Another example of express agency recognition of privacy considerations is the recent Federal Communications Commission order adopting rules banning unauthorized electronic eavesdropping. ${ }^{70}$ Although the order was an implementation of Commission authority under the Communications Act of $1934{ }^{71}$ it came only after many years of study by Congress, several state legislatures, and bar associations. The Commission pointedly stated that its order and report were based in part on information developed during hearings by the Constitutional Rights Subcommittee and the Administrative Practice and Procedure Subcommittee of the Senate. The Commission basked in accolades from Congress, the press, and the public, such as that of Senator Ervin, who commended the agency order, noting that it reflected "an increasing national interest in the right to privacy" and that the "privacy interest of the citizen and the employee needs to be a factor influencing administrative decisions in many more agencies." ${ }^{972}$

Another resource available to check personnel excesses wherever they are found is the power of the purse. At the federal level, the Bureau of the Budget, in particular, has been too little utilized by Congress and the Executive for purposes of protecting civil liberties of employees. Given responsibility for assuring that certain goals are met in the planning stage of agency programs, the Bureau has potential for assuring compliance with privacy-oriented standards and safeguards. ${ }^{73}$ It can also assure that no expenditure of funds is budgeted for instruments which Congress has prohibited by law. Within the Bureau's Office of Statistical Standards are reviewed all forms by which Government agencies propose to gather data from citizens. Two of this office's areas of interest relate to applications for federal employment and to research in the fields of personality and mental health.

The privacy issue as such is not one that has concerned the Bureau except in so far as it was inherent in some standard of "appropriateness" or "reasonableness" which reviewing officers applied. In reviewing forms they consider "whether a particular question is reasonable and warranted in view of the purpose for which the inquiry is designed and the conditions under which it is carried out" and "whether the form provides appropriately for confidentiality."74 Thus, the Bureau

\footnotetext{
${ }^{70} 3$ I Fed. Reg. 3397 (I966).

1148 Stat. 1066, 1081, r082, as amended, 47 U.S.C. $\$ \S 153,301,303$ (x964).

1s Ervin Commends F.C.C. Eavesdropping Ban, Senate Subcomm. on Constitutional Rights Press Release, March 3, 1966; Monthly Staff Report to the Senate Subcomm. on Constitutional Rights, March 7 , rg66.

${ }^{73}$ See John Gaus, Reflections on Public Aoministration I13 (1947): "I must risk the heretical statement that a good budget staff and a good personnel office will do more to preserve the liberties of the people than a good court, because they will be in operation long before a potential wrong is done. I hasten to add that they are not alternatives."

${ }^{74}$ Hearings on Invasions of Privacy by Government Agencies, sapra note 8, at 294 (testimony of Edward Crowder, Clearance Officer, Office of Statistical Standards).
} 
has approved questions of an intimate nature on the Standard Form 57 application for federal employment which relate to drinking, arrests, employment experience, and other matters. On the other hand, it has worked with the Civil Service Commission to revise questions on that form relating to personal conduct. On grounds of "appropriateness," it has disallowed a proposal to administer a well-known personality test to six-to-twelve year olds in a health examination survey. ${ }^{75}$ It also brought about the amendment or elimination of questions about socio-economic background for counselors in one government program; ${ }^{76}$ and on grounds of "irrelevancy," it caused deletion of questions on religion and political affiliations on a form which the Defense Department submitted to local civil defense officials. ${ }^{77}$

It is apparent that the Bureau was not unaware of the privacy issue, but, until recently, it had not been defined for them as worthy of being a dominating factor in reviewing decisions. The Bureau's concern reflects a pragmatic, case-by-case, sometimes intuitive, approach to the problem. ${ }^{78}$ It is predictable that the prevailing climate of concern for privacy as an interest, called to their attention by congressional inquiries and press coverage, will make the Bureau much more conscious of this as a necessary element of its work. Certainly the apparatus exists here for exerting a large measure of control. It needs only the positive action of an act of Congress or an executive order, or both.

The proposal for a Federal Data Center, which has found support in the Budget Bureau, ${ }^{79}$ is the latest fuel to be thrown on the fires already burning in congressional committees over the issue of privacy invasion. Since the Government already has over 15,000 computers in operation, the potential of a computerized data center to store and organize all the information Government gathers about private citizens, as well as about its employees, raises specters which many find too awful to contemplate. $^{80}$ While precautions reportedly would be taken to protect confidential ma-

${ }^{75} I d$. at 295 .

${ }^{70} 1 d$. at $295-96$.

गT Id. at 296.

${ }^{78}$ When asked how the issue of privacy becomes a part of the general issue of appropriateness, a Bureau spokesman replied:

"[T] he issue of privacy is implicit in very many questions that go beyond impersonal facts that are completely devoid of any such implications of intimacy.

"When we identify a question which does have a certain degree of intimacy, we give it a particularly hard look, and the issue then is, is it warranted in this case to ask this intimate question? So that the actual review proceeds in terms of the justification for it, and we end up with a judgment as to whether it is legitimate under these circumstances to pry this deeply into the respondent's affairs; and we may decide that it is or that it is not.

"This is somewhat parallel to another issue that is also implicit in a questionnaire, namely the burden of filling it out. There is some burden involved in filling out any questionnaire, and here also we ask ourselves whether the purpose to be served warrants the imposing on the respondent of this burden, which may be moderate or very great, as the circumstances may vary."

Id. at $297-98$.

${ }_{79}$ Lardner, Center for Data on Everybody Recommended, Washington Post, June 13, I966, p. A-3, cols. I-2. See also Karst, "The Files": Legal Controls Over the Accuracy and Accessibility of Stored Personal Data, pp. 359-63 supra; The New Computerized Age, Saturday Review, July 26, 1966 (symposium).

${ }^{80}$ See, e.g., I12 CoNG. REC. 12506 (daily ed. June 14, 1966) (remarks of Representative Gallagher): 
terials, the bulk of the information would be available within the Government and to state and local agencies, as well as to business and research groups. In answer to alarmed queries from Congress, a Budget Bureau representative has said that, although it does have plans to obtain statistical information on all kinds of American business for the sake of economic forecasting, there are no plans for building a personal dossier on every American citizen ${ }^{81}$ or to have personnel data files. It is too soon to condemn the data center idea out of hand before it has even been defined. Such a center could be of tremendous value in increasing the efficiency of government and aiding private business and research efforts; yet, assurances to the contrary, it could also become a central personnel center for government and industry. One thing is certain. The future of this proposal and similar ones at the state level ${ }^{82}$ should be closely watched by Congress, state legislatures, and the public for their impact on the right to privacy.

\section{Conclusion}

The contemporary American's lethargy in reacting to invasions of privacy by employers, both governmental and private, is a sad commentary on our national heritage and traditions. The type of searches made by colonial patriots were, in many respects, preferable to those of the present day which seem to search the private actions, habits, and innermost thoughts of our citizens. The insidiousness of the latter searches-made in many instances without the employee's knowledge--makes them all the more frightening. That the American public has submitted to these incursions on their liberties has undoubtedly accounted in large measure for the increasing and widespread invasions of their privacy.

It has been only recently that pressures on the executive from Congress and from labor and professional groups have been such as to halt some of these incursions. However, such belated actions are so far grossly inadequate to protect the individual's right to privacy in his employment relations, though they are steps in the right direction. The beneficial effect the federal government can have upon protecting an employee's privacy is exemplified by the recent ordering of private contractors for federal agencies to desist from using psychological tests on employees unless they are conducted as a part of a professional medical examination and with precautions

"If the Government does set up a central file or 'dossier bank' of personal data on our citizens, there will be a huge store of information at hand to feed it. That list includes tax returns, census responses, social security data, military records, security files, fingerprints, mortgage guarantees, research involving individuals, and, if state and local governments are tied into the system, such things, as school records, policye files, driving violations, and property holdings. . . . It might even be possible to pump credit reports and bank accounts into the computer. . . . [T] The proposed establishment of a Federal data bank poses dangers to the privacy of our citizens which could dwarf anything stemming from electronic eavesdropping and other modern snooping devices."

${ }^{81}$ Hearings on Government Electronic Data Processing Systems Before the Subcomm. on Census and Statistics of the House Comm. on Post Office and Civil Service, 89th Cong., 2d Sess. 20 (1966) (testimony of Harold Seidman, Ass't Director for Management and Organization, Bureau of the Budget).

${ }^{82}$ See generally id. at $244-53,255-89$. 
to ensure the privacy of the data. ${ }^{83}$ The number of private contractors dealing with the federal government includes virtually every major firm in the country, as well as many smaller ones, and because of this, the federal government's action can have a tremendous impact upon this area of employer-employee relations. The Government is, of course, equally capable of having an adverse effect in this area, as some civil libertarians have observed, and it is too early to be certain that its influence will be for the best.

Codes of ethics for government service established by Congress and directives by government agencies urging employees to place "loyalty to high moral principles and the nation above loyalty to person, party or government department" are of course unexceptionable. However, if the spirit of the Constitution is to be upheld, the employee must fully exercise his rights as a citizen to protect his own privacy as well as that of every fellow employee. Furthermore, administrators must realize that adherence to that high moral principle demands that his decisions affecting the public and his own personnel reflect a respect for the dignity of the individual and for his basic rights under our system of government. His observance of those moral principles, his devotion to the values protected by our Constitution, impose on him the duty to raise his voice against orders to utilize privacy-invading practices and devices.

\section{8gTH CONGRESS}

\section{APPENDIX}

\section{D SESSION}

\section{S. 3779}

\section{IN THE SENATE OF THE UNITED STATES}

August 26 (legislative day, August 25), 1966

Mr. ERvin (for himself, Mr. Fong, Mr. Bayh, Mr. Hruska, Mr. Smathers, Mr. Burdick, Mr. Tydings, Mr. Dirksen, Mr. Randolph, Mr. Bible, Mr. Russell of South Carolina, Mr. McCarthy, Mr. Bennetr, Mr. Fannin, Mr. Young of Ohio, Mr. Yarborougrt, Mr. Byrd of Virginia, Mr. Bartuett, Mr. Mundr, Mr. Thurmond, Mr. Mcintyre, Mr. Sparkman, Mr. Cannon, Mr. Mriler, Mr. Simpson, Mr. Jordan of North Carolina, Mr. Aliotr, Mr. Muskie, Mr. Inoure, Mr. SAltonstall, Mr. Williams of New Jersey, Mr. Tower, Mr. Prouty, Mr. Brewster, and Mr. GrIFriN) introduced the following bill; which was read twice and referred to the Committee on the Judiciary

\footnotetext{
${ }^{83}$ Private contractors for federal agencies have been ordered by the Civil Service Commission not to administer personality tests to employees execpt in the course of carefully controlled medical examinations. The order resulted from complaints received from employees regarding privacy-invading questionnaries which employers had required. See Washington Post, May 28, 1966, p. B2, cols. 6-7.
} 


\section{A BILL}

To protect the employees of the executive branch of the United States Government in the enjoyment of their constitutional rights and to prevent unwarranted governmental invasions of their privacy.

Be it enacted by the Senate and House of Representatives of the United States of America in Congress assembled,

SEction I. It shall be unlawful for any officer of any executive department or any executive agency of the United States Government, or for any person acting or purporting to act under his authority, to do any of the following things:

(a) To require, or request, or to attempt to require or request, any employee of the United States serving in the department or agency or any person seeking employment in the executive branch of the United States Government, to disclose his race, religion, or national origin, or the race, religion, or national origin of any of his forebears;

(b) To call or hold, or to sanction the calling or holding of, any assemblage, discussion, or lecture which is designed to advise, instruct, or indoctrinate any employee of the United States serving in the department or agency in respect to any matter or subject other than the performance of the task to which he is or may be assigned in the department or agency;

(c) To state or intimate, or to attempt to state or intimate, to any employee of the United States serving in any department or agency that any notice will be taken of his attendance or lack of attendance at any assemblage, discussion, or lecture held or called by any outside parties or organizations to advise, instruct, or indoctrinate any employee of the United States serving in the department or agency in respect to any matter or subject other than the performance of the task to which he is or may be assigned in the department or agency;

(d) To require or request, or to attempt to require or request, any employee of the United States serving in the department or agency to participate in any way in any activities or undertakings unless such activities are directly within the scope of his employment;

(e) To require or request, or to attempt to require or request, any employee of the United States serving in the department or agency to make any report concerning any of his activities or undertakings unless such activities are directly within the scope of his employment;

(f) To forbid or attempt to forbid any employee of the United States serving in the department or agency to patronize any business establishment offering goods and services to the general public;

(g) To require or request, or to attempt to require or request, any employee of the United States serving in the department or agency, or any person seeking 
employment in the executive branch of the United States Government, to submit to any interrogation or examination or to take any psychological or polygraph test which is designed to elicit from him information concerning his personal relationship with any person connected with him by blood or marriage, or concerning his religious beliefs or practices, or concerning his attitude or conduct with respect to sexual matters;

(h) To require or request, or attempt to require or request, any employee of the United States serving in the department or agency to support any candidate, program, or policy of any political party by personal endeavor or contribution of money or other thing of value;

(i) To coerce, or attempt to coerce, any employee of the United States serving in the department or agency to invest his earnings in bonds or other obligations or securities issued by the United States or any of its departments or agencies or to make donations to any institution or cause of any kind: Provided, however, That nothing contained in this subsection shall be construed to prohibit any officer of any department or agency of the United States Government or any person acting or purporting to act under his authority from using appropriate publicity to persuade any employee of the United States voluntarily to invest his earnings in bonds or other obligations or securities issued by the United States or any of its departments or agencies, or voluntarily to make donations to any institution or cause;

(j) To require, or request, or attempt to require or request, any employee of the United States serving in the department or agency, to disclose his assets or his liabilities or his personal or domestic expenditures or those of any member of his family: Provided, however, That this subsection shall not apply to any employee who has authority to determine final agreements which fix the tax or other liability of any person, corporation, or other legal entity, or the provisions of contracts which require expenditure of moneys of the United States in excess of $\$ 100$;

(k) To require, or request, or attempt to require or request any employee serving in the department or agency, who is under investigation for misconduct to submit to interrogation which could lead to disciplinary action without the presence of counsel or other person of his choice, if he so requests; or

(1) To discharge, discipline, or deny promotion to any employee of the United States serving in the department or agency by reason of his refusal or failure to submit to any requirement, request, or action made unlawful by this Act.

SEc. 2. Whenever any officer of any executive department or any executive agency of the United States Government, or any person acting or purporting to act under his authority, willfully violates or willfully attempts to violate any of the provisions of section I of this Act, he shall be guilty of a misdemeanor, and 
upon conviction shall be punished by a fine not exceeding $\$ 500$, or by imprisonment not exceeding six months, or by both such fine and imprisonment.

SEC. 3. Whenever any officer of any executive department or executive agency of the United States Government, or any person acting or purporting to act under his authority, violates or threatens to violate any of the provisions of section I of this Act, any employee of the United States or any person applying for employment in the executive branch of the United States Government affected or aggrieved by the violation or threatened violation may bring a civil action in his own behalf or in behalf of himself and others similarly situated against the offending officer or person in the United States district court for the district in which the violation occurs or is threatened or the district in which the offending officer or person is found to prevent the threatened violation or to obtain redress against the consequences of the violation. Such United States district court shall have jurisdiction to try and determine such civil action irrespective of the actuality or amount of pecuniary injury done or threatened, and to issue such restraining order, interlocutory injunction, permanent injunction, or mandatory injunction, or enter such other judgment as may be necessary or appropriate to prevent the threatened violation, or to afford the plaintiff and others similarly situated complete relief against the consequences of the violation. 


\section{DUKE LAW JOURNAL}

A law review edited by students of Duke University School of Law and devoted to a discussion of legal topics of current interest. Subscription Rate: $\$ 9.5^{\circ}$ per year.

Volume 1966 No. 3 (Summer) Includes:

(Single Copy Price: \$2.50)

Movie Censorship: A Swiss Comparison

by Francis William O'Brien

SUMMaRY JURISDiction IN Bankruptcy: Katchen v. LaNdy aNd

QUESTIONS LEFT UNANSWERED

by William J. Rochelle, Ir. and John L. King

The Malpractice of Psychiatrists

by Donald J. Dawidoff

Volume ig66 No. 4 (AutumN) Includes:

CoRporation Statutes: 1959-1966

by Ernest L. Folk, III

Tax Consequences of Limitations Upon the Exercise of Powers by Charles L. B. Lowndes

Comment: The Local Rules of Civil Procedure in the Federal

District Courts-A SURveY

Address Subscription and Inquiries to The Managing Editor

DUKE LAW JOURNAL

Duke University School of Law

Durham, North Carolina 27706 